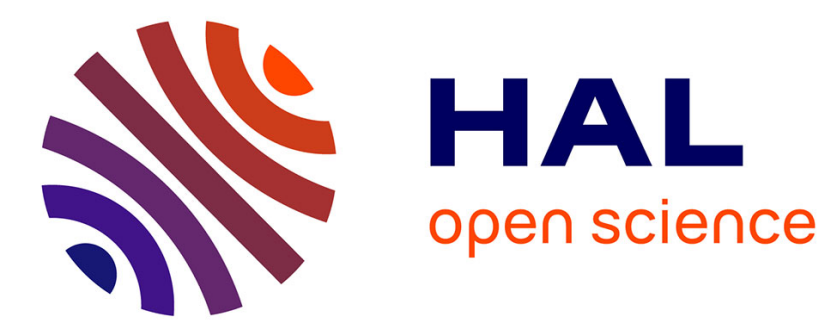

\title{
Grassland management for sustainable agroecosystems
} Gianni Bellocchi, Abad Chabbi

\section{To cite this version:}

Gianni Bellocchi, Abad Chabbi. Grassland management for sustainable agroecosystems. Agronomy, 2020, 10 (1), pp.1-5. 10.3390/agronomy10010078 . hal-02623236

\section{HAL Id: hal-02623236 \\ https://hal.inrae.fr/hal-02623236}

Submitted on 26 May 2020

HAL is a multi-disciplinary open access archive for the deposit and dissemination of scientific research documents, whether they are published or not. The documents may come from teaching and research institutions in France or abroad, or from public or private research centers.
L'archive ouverte pluridisciplinaire HAL, est destinée au dépôt et à la diffusion de documents scientifiques de niveau recherche, publiés ou non, émanant des établissements d'enseignement et de recherche français ou étrangers, des laboratoires publics ou privés. 


\title{
Grassland Management for Sustainable Agroecosystems
}

\author{
Gianni Bellocchi ${ }^{1}\left(\mathbb{D}\right.$ and Abad Chabbi ${ }^{2, *}$ \\ 1 UCA, INRAE, VetAgro Sup, UREP, 63000 Clermont-Ferrand, France; gianni.bellocchi@inrae.fr \\ 2 INRAE, URP3F, 86600 Lusignan, France \\ * Correspondence: abad.chabbi@inrae.fr; Tel.: +33-549-556-178
}

Received: 11 December 2019; Accepted: 29 December 2019; Published: 6 January 2020 updates

\begin{abstract}
Knowledge on sustainable grassland management is available in the large body of literature. However, it is unclear where to look for it, and what is really relevant to the many interrelated challenges of sustainable grassland management. This special issue illustrates options to fill some of those gaps. This editorial introduces the Special Issue entitled "Grassland Management for Sustainable Agroecosystems". Two review articles deal with (i) concepts for monitoring grassland degradation (by Tiscornia et al. Agronomy 2019, 9, 239) and (ii) impacts of alternative management practices and disturbances (by Wagle and Gowda et al. Agronomy 2018, 8, 300). One paper (by Steiner et al. Agronomy 2019, 9, 699). summarized a series of papers of the special issue. Other topics covered include four main aspects: (I) Landscape features (Ravetto Enri et al. Agronomy 2019, 9, 333), two papers by Northup et al. Agronomy 2019, 9, 329, Northup et al. Agronomy 2019, 9, 281, and Ma et al. Agronomy 2019, 9, 238; (II) climate (Zhou et al. Agronomy 2019, 9, 219, Starks et al. Agronomy 2019, 9, 235, and Moinet et al. Agronomy 2019, 9, 124); (III) soil fertility (Franzluebbers et al. Agronomy 2019, 9, 204, Poblete-Grant et al. Agronomy 2019, 9, 191); and (IV) one on modeling (Puche et al. Agronomy 2019, 9, 183). Two additional papers are from Andueza et al. Agronomy 2019, 9, 273 (on the feed value of barn-dried hay) and Úbeda et al. Agronomy 2019, 9, 340 (on the role of prescribed burns).
\end{abstract}

Keywords: continuous and rotational grazing; phosphorous availability and uptake; potential management; site use intensity; soil macronutrient responses and distributions; soil organic carbon and nitrogen; soil respiration

\section{Introduction}

Grasslands should no longer be considered only for global food supply contributing to ruminant milk and meat productions, but also, and above all, as a source of production of ecosystem services that contribute to the sustainability of agriculture. The intensification of agricultural production has been accompanied by a specialization of production systems, which has led to a spatial separation of agriculture and livestock and an excessive standardization of territories [1]. This has led to unacceptable environmental impacts on society. Grasslands, like forests, play a key role in this regard (i) by strongly coupling the cycles of $\mathrm{C}, \mathrm{N}$, and $\mathrm{P}$, thus limiting emissions to the hydrosphere and atmospheres, and (ii) in acting positively on the dynamics of biodiversity. However, the intensification of grasslands aimed at maximizing their production function tends to decouple the $\mathrm{C}$ and $\mathrm{N}$ cycles through the animal and therefore minimize their environmental function [2]. A compromise must therefore be sought through reasoned intensification. In this regard, the importance of studies on grasslands has intensified during the last years, as awareness has grown that societies and individuals gain important benefits from these ecosystems [3]. The location of grassland vegetation in the agricultural landscape contributes greatly to soil erosion control, and this is often coupled to other services relating to water supply and regulation, carbon sequestration, and soil fertility [4-6]. These roles are widely recognized by actors in 
the agricultural world and by public policies. On the recognition that species-rich grasslands are a source of multiple ecosystem services, several contributions have provided the ground for innovative management practices that can increase fodder production, while, at the same time, enhancing other services like pollination, biological control, climate regulation, and soil conservation [7-9].

The renewed interest in grasslands, observed since the turn of the 21st century, is precisely driven by a greater recognition of the importance of grassland and livestock grazing systems in relation to soil conservation, biodiversity promotion, farming communities' stabilization, and the provision of a wealth of natural ecosystem services [10]. The special issue is an excellent overview of the management actions taken on different types of grasslands worldwide, with particular care on the Great Plains of North America. As known, this area is one of the most hit zones of the world because native grasslands have mostly disappeared in the past century due to agricultural expansion. The remaining prairie ecosystems are important for livestock grazing and provide additional benefits including habitat for a diversity of avian, terrestrial, and aquatic species, and the regulation of hydrological and carbon cycles.

\section{Special Issue Overview}

The special issue of Agronomy entitled "Grassland Management for Sustainable Agroecosystems" publishes 15 articles that provide insights into challenges of, and possible solutions to, sustainable grassland management. It contains two review articles dealing with: (1) Concepts for monitoring grassland degradation and (2) the impacts of alternative management practices and disturbances, including restoration. We add that while describing the initial results from a major grazing experiment in the Southern Great Plains of the USA, Steiner et al. ([11]. introduced and summarized a series of papers in this special issue. This is probably the article that most readers who are unfamiliar with this field of research should begin with.

The review by Tiscornia et al. [12] provides the background and context to the study of grassland degradation, clarifying the related drivers, processes, and consequences. This is important because grassland degradation has multi-casual drivers. The possibility of a common interpretation of the degradation issue over different scales is certainly fascinating. In fact, this paper is both a literature and an expert analysis on how the grassland degradation is defined and studied across the world, and more particularly, for the pasture ecosystems of the Region of Río de La Plata (across the central-eastern part of Argentina, most of Uruguay, and southern Brazil). The importance of natural grasslands to food security, the provision of ecosystem services, and the economy of many developing countries such as Uruguay, Argentina, and Brazil, implies that their degradation is a major political, economic, and environmental issue. This importance is reinforced by the experts' perception that the effects of livestock production intensification and climate change can increase degradation. The review paper has the merit of proposing a novel conceptual model, where multiple drivers (e.g., rainfall variability and overgrazing) operate simultaneously and interact in different site-specific conditions like soil types, bioclimatic zones, and history of grazing. To advance in the knowledge of grassland degradation process, the authors represented such interactive effects in a conceptual state and transition models of the main processes affected (e.g., decreased primary production by a reduced leaf area index, reduced plant species diversity by an increment of interspecific competitive exclusion for light) and the consequences of management practices.

The review [13] of Wagle and Gowda compiled several information about how multiple aspects of tallgrass prairie respond to a variety of treatments applied in experimental settings, with some of those actually being common management practices. In fact, tallgrass prairie grasslands can range from unmanaged low productive systems to highly managed, high-productive systems. Notably, whether nitrogen $(\mathrm{N})$ fertilization is a widely used management practice to improve the productivity of managed prairie grasslands for grazing or hay harvests, a judicious use of $\mathrm{N}$ fertilization is recommended to minimize undesirable and invasive species and to maintain healthy native prairie stands. There are increasing efforts from government and private organizations to restore diverse prairies in agricultural sites, but restored prairies show a tendency of community composition to shift towards $\mathrm{C} 4$ grass 
dominance and lower soil quality compared to native remnants. Prescribed fire and grazing together can create highly productive, diverse, and heterogeneous grassland systems because of the modulation of the fire effect on plant diversity by reducing the dominance of $\mathrm{C} 4$ grasses and increasing the diversity and richness of species.

The role of prescribed burns was also addressed in the study conducted by Úbeda et al. [14] in Catalonia (Spain). When alternating with livestock (goat) grazing, it may be an acceptable way to promote abandoned terraces into pasture and reduce the risk of fire.

The other papers addressed three broad topics: Landscape features, climate, and soil fertility. We add the contribution of Andueza et al. (France) [15], who highlighted a higher feed value (for digestibility and intake) of barn-dried hay (hay is cut, wilted in the field, and then further dried in a burn) obtained from permanent grasslands than fresh forage.

\subsection{Landscape Features}

Sustainable grassland management involves highly complex challenges. There is a need to take into account all framework conditions, including the soil resources, water supply, and the climatic conditions, among others. A study conducted in the Italian Alps (Ravetto Enri et al.) [16] provided new knowledge to support sheep grazing management, as it highlighted that environmental and management factors, such as distance from night penning areas, distance from water, and slope, can be reliable proxies of the pasture use intensity by grazing sheep. This is particularly relevant, considering that Alpine pastures are characterized by a high spatial heterogeneity due to changes in topography and vegetation.

Landscape features included within paddocks, including organization of water and other features, require higher attention because they influence the (non-uniform) distribution of plant-available macronutrients fluxes beyond the stocking method adopted. The potential to define grazing effects on macronutrient distribution was addressed in two contributions by Northup et al. $[17,18]$ in central Oklahoma (USA), while Ma et al. [19] highlighted the need of high spatial and temporal resolution images to monitor the tallgrass prairie landscapes (notably shrub encroachment, for which grazing management effects are hardly detectable).

\subsection{Climate Change}

Numerous indicators confirm the reality of climate change, which should affect several grasslands and forage systems not only through the average evolution of climatic variables (temperature, precipitation, and $\mathrm{CO}_{2}$ concentration), but also by their interactions and increasing their variability. Considering the inertia of the climate system, grassland management adaptation is now inevitable whatever additional efforts we manage to deploy to reduce greenhouse gas emissions. Contributions from American grassland systems indicating that adaptive grazing management (adjustment in stocking rates and season of use to adapt to changing climatic conditions) instead of a fixed management system might be better for farmers to cooperate with changing climatic conditions (Zhou et al.) [20]. Thanks to the study of Starks et al. [21] in Konza Prairie, Kansas (USA), the standardized precipitation and evaporation index (SPEI) is offered as a suitable predictive tool of aboveground grassland or forage mass. Yet not conclusive about which of mowing or grazing enhance drought resilience, Moinet et al. [22] found in a French study that different management practices and decisions strongly contribute to determine the response of soil carbon dynamics to changes in soil water content. In other words, grassland management practices can change the relationship between soil respiration and its water content.

\subsection{Soil Fertility and Modeling}

Grazing lands typically have greater soil organic $C$ and $N$ contents than other agricultural land uses. An important aspect of regaining full functionality of grasslands focuses on how animals are stocked and allowed to graze available forage. Grazing livestock is an important regulator of 
how $\mathrm{C}$ and $\mathrm{N}$ in grasslands are partitioned in the ecosystem, but this may not be discernible in the short-medium time (Franzluebbers et al.) [23]. Though further testing in long-term field experiments is required, Poblete-Grant et al. [24]. evoked the use of poultry manure compost as a strategy to replace inorganic fertilizers. It is known that current and past management practices interact with soil and environmental factors in determining pasture and animal productivity, and soil organic carbon stocks. These multiple, complex, and interacting factors can realistically only be assessed through modeling approaches, as the number of possible interactions exceeds the number that could feasibly be studied experimentally. At the same time, models need to be tested and verified against real-world observations to build confidence in their ability to accurately describe the patterns we are interested in, in particular, the effect of different management options in enhancing soil organic carbon storage without compromising pasture productivity. The contribution from Puche et al. [25] is a modeling work on mown and grazed paddocks in France, equipped with eddy-covariance (EC) measuring systems. The model used, CenW, confirms the difficulty of simulating grazing systems where EC devices may not completely detect $C$ losses.

\section{Conclusions}

Grasslands produce forage to support livestock farming. Grassland ecosystems are also a reservoir of biological diversity and soil carbon, and the lever of multiple ecosystem services supporting the life and the economy of various communities and territories. This special issue gathered research investigations that relied on the grassland management, with various objectives and methodologies, showing to which extent grassland ecosystems are the object of multiple researches from large communities of scientists. Furthermore, this special issue also demonstrated ways to address the complexity of sustainable grassland management and its current and future challenges with respect to climate change and landscape features.

Author Contributions: A.C. and G.B. wrote this editorial for the introduction of the Special Issue, entitled "Grassland Management for Sustainable Agroecosystems", of Agronomy, and edited the Special Issue. All authors have read and agreed to the published version of the manuscript.

Funding: This research received no external funding.

Acknowledgments: We thank all authors who submitted their valuable papers to the Special Issue, entitled "Grassland Management for Sustainable Agroecosystems", of Agronomy.

Conflicts of Interest: The authors declare no conflict of interest.

\section{References}

1. Lemaire, G.; Gastal, F.; Franzluebbers, A.; Chabbi, A. Grassland-cropping rotations: An avenue for agricultural diversification to reconcile high production with environmental quality. Environ. Manag. 2015, 65, 1065-1077. [CrossRef] [PubMed]

2. Rumpel, C.; Chabbi, A. Plant-soil interactions control CNP coupling and decoupling processes in Agroecosystems with perennial vegetation. In Agro-Ecosystem Diversity: Reconciling Contemporary Agriculture and Environment Quality; Lemaire, G., De Faccio Carvalho, P.C., Kronberg, G., Recous, S., Eds.; Elsevier Academic Press: Cambridge, MA, USA, 2019; pp. 3-13.

3. Bengtsson, J.; Bullock, J.M.; Egoh, B.; Everson, C.; Everson, T.; O'Connor, T.; O'Farrell, P.J.; Smith, H.G.; Lindborg, R. Grasslands-More important for ecosystem services than you might think. Ecosphere 2019, 10, e02582. [CrossRef]

4. Souchère, V.; King, C.; Dubreuil, N.; Lecomte-Morel, V.; Le Bissonnais, Y.; Chalat, M. Grassland and crop trends: Role of the European Union Common Agricultural Policy and consequences for runoff and soil erosion. Environ. Sci. Policy 2003, 6, 7-16. [CrossRef]

5. Pilgrim, E.S.; Macleod, C.J.A.; Blackwell, M.S.A.; Bol, R.; Hogan, D.V.; Chadwick, D.R.; Cardenas, L.; Misselbrook, T.H.; Haygarth, P.M.; Brazier, R.E.; et al. Interactions among agricultural production and other ecosystem services delivered from European temperate grassland systems. Adv. Agron. 2010, 109, 117-154. 
6. Hou, R.; Yu, R.; Wu, J. Relationship between paired ecosystem services in the grassland and agro-pastoral transitional zone of China using the constraint line method. Agric. Ecosyst. Environ. 2017, 240, 171-181.

7. Holland, J.M.; Douma, J.C.; Crowley, L.; James, L.; Kor, L.; Stevenson, D.R.; Smith, B.M. Semi-natural habitats support biological control, pollination and soil conservation in Europe. A review. Agron. Sustain. Dev. 2017, 37, 31. [CrossRef]

8. Wehn, S.; Hovstad, K.A.; Johansen, L. The relationships between biodiversity and ecosystem services and the effects of grazing cessation in semi-natural grasslands. Web Ecol. 2018, 18, 55-65. [CrossRef]

9. Johansen, L.; Taugourdeau, S.; Hovstad, K.A.; Wehn, S. Ceased grazing management changes the ecosystem services of semi-natural grasslands. Ecosyst. People 2019, 15, 192-203. [CrossRef]

10. Sollenberger, L.E.; Kohmann, M.M.; Dubeux, J.C.B.; Silveira, M.L. Grassland management affects delivery of regulating and supporting ecosystem services. Crop Sci. 2019, 59, 441-459. [CrossRef]

11. Steiner, J.L.; Starks, P.J.; Neel, J.P.; Northup, B.; Turner, K.E.; Gowda, P.; Coleman, S.; Brown, M. Managing Tallgrass Prairies for Productivity and Ecological Function: A Long-Term Grazing Experiment in the Southern Great Plains, USA. Agronomy 2019, 9, 699. [CrossRef]

12. Tiscornia, G.; Jaurena, M.; Baethgen, W. Drivers, process, and consequences of native grassland degradation: Insights from a literature review and a survey in Río de la Plata grasslands. Agronomy 2019, 9, 239. [CrossRef]

13. Wagle, P.; Gowda, P.H. Tallgrass prairie responses to management practices and disturbances: A review. Agronomy 2018, 8, 300. [CrossRef]

14. Úbeda, X.; Alcañiz, M.; Borges, G.; Outeiro, L.; Francos, M. Soil Quality of abandoned agricultural terraces managed with prescribed fires and livestock in the municipality of Capafonts, Catalonia, Spain (2000-2017). Agronomy 2019, 9, 340. [CrossRef]

15. Andueza, D.; Picard, F.; Pradel, P.; Theodoridou, K. Feed value of barn-dried hays from permanent grassland: A comparison with fresh forage. Agronomy 2019, 9, 273. [CrossRef]

16. Ravetto Enri, S.; Gorlier, A.; Nota, G.; Pittarello, M.; Lombardi, G.; Lonati, M. Distance from Night Penning Areas as an Effective Proxy to Estimate Site Use Intensity by Grazing Sheep in the Alps. Agronomy 2019, 9, 333. [CrossRef]

17. Northup, B.K.; Starks, P.J.; Turner, K.E. Soil macronutrient responses in diverse landscapes of southern tallgrass to two stocking methods. Agronomy 2019, 9, 329. [CrossRef]

18. Northup, B.K.; Starks, P.J.; Turner, K.E. Stocking methods and soil macronutrient distributions in Southern tallgrass paddocks: Are There Linkages? Agronomy 2019, 9, 281. [CrossRef]

19. Ma, S.F.; Zhou, Y.; Gowda, P.H.; Chen, L.; Starks, P.; Steiner, J.L.; Neel, J.S.N. Evaluating the impacts of continuous and rotational grazing on tallgrass prairie landscape using high-spatial-resolution imagery. Agronomy 2019, 9, 238. [CrossRef]

20. Zhou, Y.T.; Gowda, P.H.; Wagle, P.; Ma, S.F.; Neel, J.S.N.; Kakani, V.G.; Steiner, J.L. Climate effects on tallgrass prairie responses to continuous and rotational grazing. Agronomy 2019, 9, 219. [CrossRef]

21. Starks, P.J.; Steiner, J.L.; Neel, J.S.N.; Turner, K.E.; Northup, B.K.; Gowda, P.H.; Brown, M.A. Assessment of the standardized precipitation and evaporation index (SPEI) as a potential management tool for grasslands. Agronomy 2019, 9, 235. [CrossRef]

22. Moinet, G.Y.K.; Midwood, A.J.; Hunt, J.E.; Rumpel, C.; Millard, P.; Chabbi, A. Grassland management influences the response of soil respiration to drought. Agronomy 2019, 9, 124. [CrossRef]

23. Franzluebbers, A.J.; Starks, P.J.; Steiner, J.L. Conservation of Soil Organic Carbon and Nitrogen Fractions in a Tallgrass Prairie in Oklahoma. Agronomy 2019, 9, 204. [CrossRef]

24. Poblete-Grant, P.; Biron, P.; Bariac, T.; Cartes, P.; de La Luz Mora, M.; Rumpel, C. Synergistic and antagonistic effects of poultry manure and phosphate rock on soil P availability, ryegrass production, and P Uptake. Agronomy 2019, 9, 191. [CrossRef]

25. Puche, N.; Senapati, N.; Flechard, C.R.; Klumpp, K.; Kirschbaum, M.U.F.; Chabbi, A. Modeling carbon and water fluxes of managed grasslands: Comparing flux variability and net carbon budgets between grazed and mowed systems. Agronomy 2019, 9, 183. [CrossRef]

(C) 2020 by the authors. Licensee MDPI, Basel, Switzerland. This article is an open access article distributed under the terms and conditions of the Creative Commons Attribution (CC BY) license (http://creativecommons.org/licenses/by/4.0/). 